Modeling, Identification and Control, Vol. 30, No. 3, 2009, pp. 87-100, ISSN 1890-1328

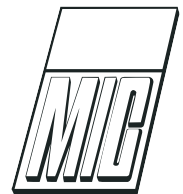

\title{
Hooked on a New Technology: The Automation Pioneers in Post-War Norway*
}

\author{
Stig Kvaal
}

Department of Interdisciplinary Studies of Culture, Center for Technology and Society, Faculty of Humanities, Norwegian University of Science and Technology (NTNU), NO-7491 Trondheim, Norway. E-mail: stig.kvaal@ntnu.no

\begin{abstract}
This paper presents the initial activities in servo engineering in Norway originating in the early 1950s based on contacts at the Massachusets Institute of Technology. The activities were initiated by a small group of servo enthusiasts who, through the Feedback Control Committee in the research council, managed to coordinate national activities and establish strong research groups in Trondheim, Bergen and Oslo. After the initial phase of establishing the research groups, there was a continuous strong focus on connections with industry and industrial applications. In the mid-1960s the committee was strengthened and became the Automation and Data Processing Committee. The initial group of automation pioneers have left a lasting impact on the academic and industrial fields of servo engineering and automation in Norway.
\end{abstract}

Keywords: Automation Pioneers, Feedback Control Committee, NTNF, Norway, 1950s, 1960s

\section{Automation as Technology and Politics}

During the 1940s new theories and technology were developed for automation and control of processes. Initially, the technology was referred to as servo engineering $^{1}$ and control engineering, but also automation technology or cybernetics. The basic technical elements of this new field of engineering were developed during World War II, when the need for speed and precision of different weapon systems led to a rapid development of analog computers, servo engineering components and basic electronics.

The American mathematics professor Norbert

\footnotetext{
* The author has largely based the article on Kvaal (1991). Translation by MIC editors G. Hovland and M. Breivik.

${ }^{1}$ Even if these terms strictly speaking do not cover the same fields, they will be used in this article in a way similar to the historic development. The use of the terms developed gradually, but not in a consistent way. Servo engineering was the most common term used in the 1950s. In the 1960s it gradually became more common to use the terms control engineering and/or automation.
}

Wiener published a theoretical foundation for control of complex systems (Wiener (1948)). These systems could be living organisms, society or machines. The new field of science was called cybernetics, named after the Greek word for steersman - kybernetes ${ }^{2}$.

The new impulses also reached Norway. By the beginning of the 1950s the first Norwegian engineers travelled abroad to gain knowledge about the mysteries of servo engineering. Many of them looked to the west and travelled to the USA. Back in Norway, inspired and convinced of the technology's possibilities, this small group of young Norwegian engineers initiated projects in this new field of research. These servo enthusiasts, which we will call them, saw many application areas for the new technology, and they saw it as an important part of the modernisation offensive which characterised the Norwegian post-war society. Automation technology represented something new, and the expectations were formed by optimistic views of the future.

In December 1954 the Royal Norwegian Council for

\footnotetext{
${ }^{2}$ For the background and the early development of automation, see for example Noble (1986) and Andersen (1986).
} 
Scientific and Industrial Research (Norges TekniskNaturvitenskapelige Forskningsråd, NTNF) created a Feedback Control Committee (Servoteknisk Utvalg, $\mathrm{STU})^{3}$. Internally, the members of this committee called themselves the 'Committee for Modern Things'. STU existed for twelve years until the name and mandate were changed towards the end of 1966. From the beginning, the work of STU was focused towards supporting two main areas: the research institutes and the industry. The academic competence at the research institutes had to be established and results had to be transferred to the industry. Early it became clear that the difficulty lay in the latter part: to transfer research results to the industry.

The progress of society and technology can not be seen isolated from each other. Engineers did not develop technology alone, but sought a connection with progress in society. Such connections were established through scenarios where technology and social progress were woven together. The presentation of technology becomes as important as the knowledge and machines. Technology is woven into and becomes a part of society and culture as a whole. Among the servo enthusiasts such visions were prominent and well formulated, see also Callon (1987). The activities of the pioneers appeared in many ways as 'missionary work' for the 'good cause' (Holberg (1990)).

The development was formed through a process of participation where several actors influenced the result. Automation technology was the focal point of a negotiation process between different types of actors. In addition to the STU and different organisations connected to this committee, the research institutes for technology and natural sciences, NTNF, the industry, the Norwegian Confederation of Trade Unions (Landsorganisasjonen, LO) and the governing Labour Party (Det Norske Arbeiderpartiet, DNA) were the central actors in this process.

By focusing on the STU we will follow the process where technology was 'negotiated'. By using Bruno Latour's words, we will follow science in action (Latour (1987)). In this way, we make the actors' strategies, choices and controverses the focus of our study. The technology itself is put in the background, even if it also functioned as an actor in the negotiations by opening possibilities and defining constraints for the strategies of the other actors. With this perspective, this article focuses on the strategies of the STU to build up a solid academic environment in the field of servo engineering in Norway and to gain entry to Norwegian industry.

\footnotetext{
${ }^{3}$ Sometimes also translated as Control Engineering Committee or Steering Committee for Control and Automation Technology, see for example NTNF catalogues from 1957 and 1963, and the MIC editorial $1994 \mathrm{Vol} 15$, No 3.
}

\section{Machines and Visions for Society - The Norwegian Servo Enthusiasts}

How did the Norwegian pioneers view the new discipline? It seems obvious that it was not all about theories and technology to automatically control processes. There was more involved. For the servo enthusiasts automation almost became 'magic', not only for developing efficient machines and factories, but also for developing a good society. In Vi Vet (1952) two of the pioneers described the technology in the following way: Servo engineering crosses traditional fields of science. It finds applications and makes use of nearly all technical fields, and it should also be used on social problems.

From the servo enthusiasts such visions were expressed in many ways. On one hand arguments were made for automation as a tool for better working and living conditions. On the other hand arguments based on economics and corporate finance were also used. Advantages such as new products, productivity, profitability, higher product quality and better utilization of resources were often put forwards. At the same time many of the engineers were interested in and fascinated by the technology itself, which was a challenge of dimensions for young and ambitious engineers. Blakstad (1960) expressed it this way: Most of the engineers working in this field feel a boyish happiness by watching the processes and machines working automatically. It is something appealing, something fun, and it is easy to be carried away.

In the dreams of the fully automatic factory it was envisioned production of goods with little or no human effort. Technocratic visions of automation as an instrument and management tool to create the good society were incorporated in what can be called a dream of control. These ideas merged with the growth and welfare politics of the post-war years into a Norwegian servo dream: a mirage of a future welfare society. The servo enthusiasts wanted to guide the society in this direction, or as Balchen ${ }^{4}$ expressed it: As engineers our task is to develop technicians' tools towards completeness and to create new methods which assist humans in their daily work. But, we also hold the responsibility to make sure that our creations serve to the good and do not fall into the hands of unscrupulous individuals who push human values aside for greater financial benefits and power. Our responsibility is large and we must always be aware of the consequences.

In many ways the dreams can be viewed as technological visions with a social democratic flavor. This does not mean that the visions of the servo engineers

\footnotetext{
${ }^{4}$ Balchen (Unknown date).
} 
and the program formulations of DNA were identical. However, the visions of the engineers can be seen as a scientific variant of the DNA perspectives for growth and prosperity. In these visions automation technology was marketed both in scenarios for the good times ahead and as an answer to the prevailing problems of a small workforce, low productivity, etc. The servo enthusiasts can in many ways be seen as 'knights of technology' who by their knowledge about new technology wanted to lead the modernisation of Norwegian industry in particular and the entire country in general.

The post-war years in Norway were characterised by a modernisation offensive. The welfare state should be realised by establishing a strong and competitive industry. Activities leading to higher productivity were therefore prioritised. It was argued primarily for cost reductions by traditional rationalisation, advantages of scale and a focus on comparative advantages related to cheap electric hydro power. These focus areas can be characterised as the work and capital strategy of the industrial politics and it was the prevailing strategy in post-war Norway (Kvaal (1994)).

Based in the research institutions for science and technology a group of research enthusiasts, worked for a stronger focus on knowledge and development of new technology for the industry. As an extension of this, they also worked for a stronger connection between the research and industrial politics. This strategy can be characterised as the science and technology strategy.

The group of servo engineers worked hard to get acceptance for their ideas. By focusing on different elements of technology, they managed to get connected with the science and technology strategy as well as the prevailing work and capital strategy. The focus on technology enabled connections with outsider groups which focused on the science and technology strategy. The focus on the significance of automation for the rationalisation and productivity activities enabled the connections with the work and capital strategy.

\section{Initial Servo Activities in Norway}

Early in the 1950s the first initial activities in servo engineering started in Norway. In this regard a course in servo engineering organised by the Norwegian Society of Chartered Engineers (Norske Sivilingeniørers Forening, NIF) in 1949 was particularly important. The course was given by professor Donald P. Campbell from the Massachusetts Institute of Technology (MIT). This course marked in many ways the beginning of the servo activities in Norway, mainly by giving important impulses to further studies for many of the engineers who would later take leading roles in the national servo engineering field.
After a while activities were also initiated at several Norwegian research institutions. At the Norwegian Defence Research Establishment (Forsvarets Forskningsinstitutt, FFI) a servo group was established in the department for ASDIC (Allied Submarine Detection Investigation Committee). In the civilian area a group at the Institute for Nuclear Power (Institutt for Atomenergi, IFA) and Christian Michelsen Institute (CMI) had worked for some time with control engineering problems by establishing the uranium reactor at Kjeller. Likewise, activities were being initiated at the Research Institute for Electricity Supply (Elektrisitetsforsyningens Forskningsinstitutt, EFI) and the Department of Physics at the University of Oslo, as well as other research institutes, see Jenssen (1950), Njølstad and Wicken (1997) and Njølstad (1999).

The contact between the servo groups was established relatively early. The driving forces in the groups were all persons around 30 years of age. While these groups kept contact with each other, there was no coordinated plan for recruitment to and building of the servo research environments. After an initiative from CMI the research council NTNF therefore convened central representatives from the different research groups in addition to three representatives from the industry to discuss the case and to develop guidelines for future work.

The first meeting was organised by the end of 1950 . The meeting concluded that coordinated activities using servo engineering should be started. The general attitude was that good solutions were needed only for a few selected problems, which in turn would lead to subsequent activities. The group was convinced that all they had to do was to start activities with a few concrete problems. This would be sufficient to convince the industry of the benefits of automation, see Feedback Control Committee (1950). The level of optimism was clearly high.

After the first meeting, Haakon Sandvold (CMI) was engaged by NTNF to establish contact with the research institutions interested in servo engineering. One of his initial tasks was to visit Norwegian companies to map the needs of the industry. The level of optimism expressed at the initial servo meeting turned out not to exist at the same level in industry. Feedback from the industry was moderately positive, but no one came forward with tasks they wanted addressed straight away (Sandvold (1951)). Even if there was a certain initial interest, there was no market for the new technology in Norwegian industry in the early 1950s.

The lack of response from actors in the Norwegian industry may have been the reason why three Norwegian servo engineers started discussions of establishing their own business. During the summer of 1953, 
Haakon Sandvold, Karl Holberg and Erik Klippenberg visited the servo laboratory at MIT. In this environment the first plans for a Norwegian servo factory were made. The factory should produce components for servo systems, and the three engineers visualised a production of components which did not require a large amount of raw materials, but depended on materials of high quality and technical skills. As for the products, the engineers were in a good position since production and American license rights could be acquired through Campbell and MIT. After the initial start-up phase, the plan was to develop and produce their own components (Sandvold (1953)).

The market opportunities, product types and financial aspects were all evaluated as very promising. In addition, competent engineers existed. Even under these circumstances, the factory was never built. What happened? The limited number of competent people was probably the main reason why the servo factory was never established. The establishment of a new factory would result in a loss of key engineers at the research institutions. Without backing from specialists in the research institutes, it was believed that the factory would struggle. The three engineers had been too optimistic. Since the research institutions would not let go of their servo engineers, the plans for a Norwegian servo factory had to be given up.

The servo factory was the first initiative to transfer knowledge to industrial production. At the time, the research environment was too fragile to allow such a drainage of servo engineers. The limited number of such engineers was the main challenge in the early $1950 \mathrm{~s}$. The goal of establishing production of Norwegian servo equipment, in line with the science and technology strategy, was, however, not abandoned, even if the first attempt stranded. The problems the servo engineers faced in their attempt to establish industrial production highlighted the need to strengthen the national competence in the field. This experience shaped the priorities for the activities to come.

\section{A Stronger Network}

Even if some servo activities had started in the early 1950 s, they were in a fragile state. As time passed, however, more research groups initiated activities in the field of servo engineering. At the Norwegian Institute of Technology (Norges Tekniske Høgskole, NTH) in Trondheim a group was established under the leadership of Jens Glad Balchen. At the Central Institute for Industrial Research (Sentralinstitutt for Industriell forskning, SI) in Oslo a group had also started. For both groups the effort was focused on building computers; the analog machine DIANA in Trondheim, see
Fig. 1, and the electronic computer NUSSE in Oslo. At the same time, CMI in Bergen was in the process of establishing a servo group around Haakon Sandvold. Despite activities at several places, 'Servo-Norway' was still synonymous with a handful of enthusiasts.

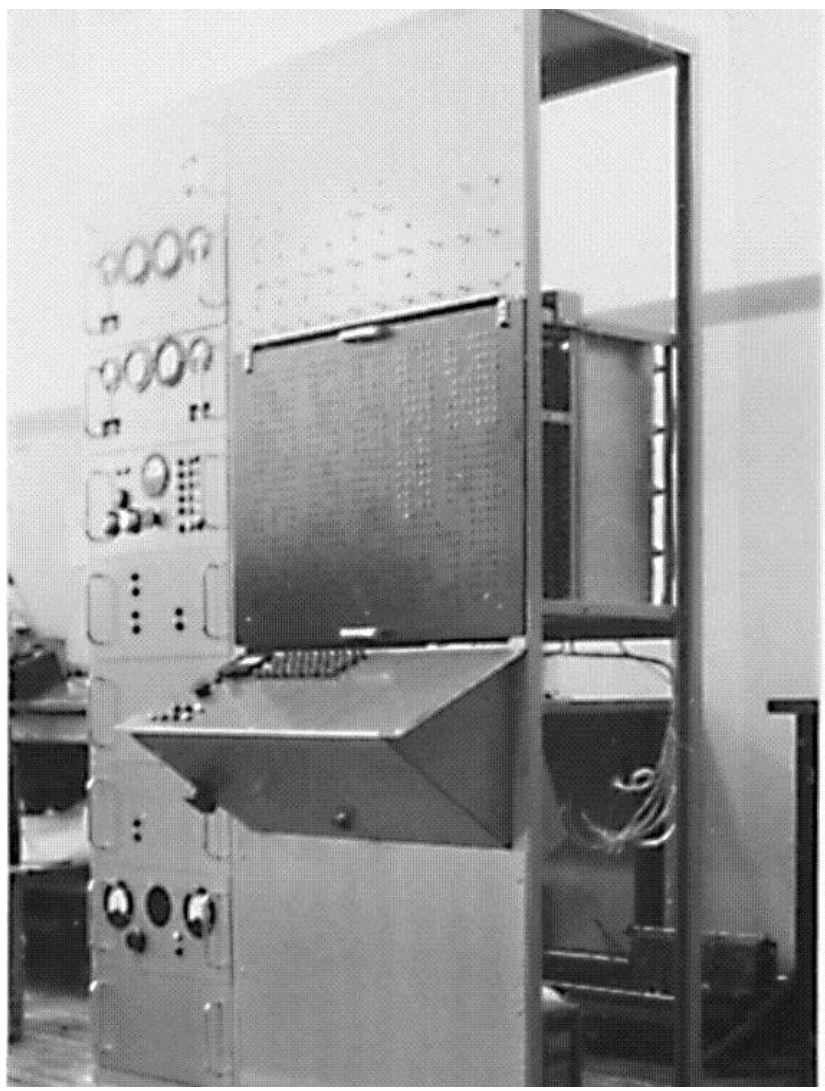

Figure 1: The analog computer DIANA developed in Trondheim for solution of differential equations and control of processes and lathes.

In parallel with establishment of the research environments the servo enthusiasts formed a network based on their activities. In 1953 they decided to meet regularly to discuss academic progress. This was the beginning of the Servo Meetings ${ }^{5}$ : an informal forum where researchers and engineers came together to exchange information about projects and activities (Holberg (1954)).

As the servo groups at the research institutions increased in numbers and size, the need for coordination also increased. To avoid that the distributed activity and lack of people and equipment became a restriction for the activities, NTNF was asked to support the research and development work and to establish a committee to coordinate the activities (Sandvold (1954)).

\footnotetext{
${ }^{5}$ The Servo Meetings are still active today 56 years later, representing one of the oldest control engineering seminars in the world
} 
NTNF was established in 1946 to coordinate the technological and scientific research in Norway (Kvaal (1997)). The tasks of NTNF were many, and it is obvious that the small administration could not have detailed knowledge and overview in all the different disciplines. From the beginning, NTNF therefore delegated the preparation of more comprehensive cases to different specialist committees. These committees were assigned the task of investigating needs for equipment and activities in their respective disciplines. In addition to processing cases and applications, the committees were also a part of a networking initiative by involving different institutions in their work (Barlaup (1956)).

In December 1954, the initiative from the servo enthusiasts resulted in NTNF creating a Feedback Control Committee with representatives from both the research institutions and the industry. The mandate for the committee was: Propose necessary activities to bring servo engineering forwards, work for an appropriate coordination of the institutes' activities in the field, function as an advisory unit for NTNF and support the implementation of the selected activities (NTNFarchive (1954b)).

The committee started functioning from January 1955 and the members were: Haakon Sandvold (CMI, chair), Jens Glad Balchen (NTH), Karl Holberg (FFI), Håkon Buset (SI), Frans Aubert (Norsk Hydro) and Wilhelm Blakstad (DeNoFa). Later, Anthon Fiksdahl (Kværner Bruk) and Ibb Høivold (CMI) joined the committee, in 1957 and 1958, respectively. The committee quickly established itself as a centre of power in the national servo environment.

One of the first tasks the STU started working on was a survey of the needs for instrumentation and automatic control in Norwegian industry. Financed by the Norwegian Productivity Institute (NPI), Sandvold, Buset and Campbell visited industrial companies, research institutes and other institutes around the country. The results from the survey were presented by Campbell et al. (1956). The report gave a bleak picture. Regarding applications of automatic control the situation of most of the industry groups was described as deficient. According to the authors the reason for the deficiency was caused mainly by the lack of qualified engineers, which was caused by the fact that the national education capacity in automatic control was inadequate. In line with these observations, the authors concluded: Before a significant increase in productivity by use of automation can be achieved, a large number of engineers with skills in instrumentation, servomechanisms and process control must become available for the different branches of industry.

The authors concluded that the educational activi-

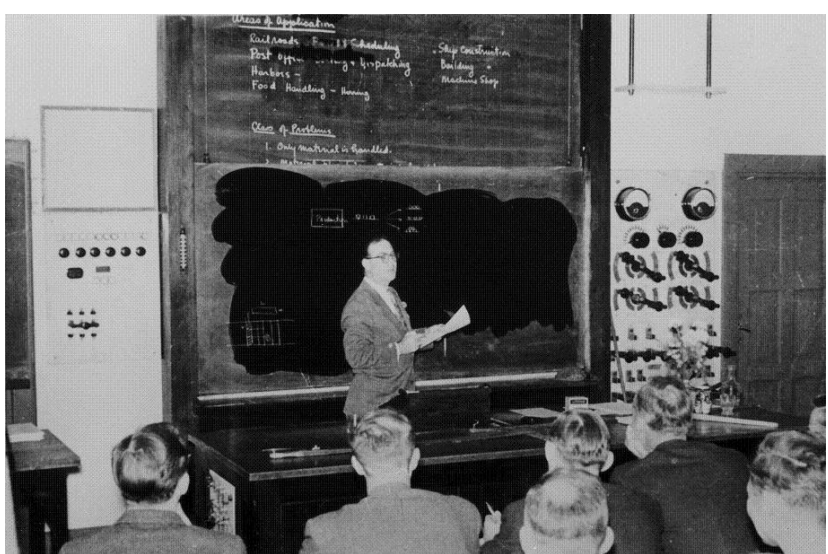

Figure 2: Professor Donald P. Campbell teaches servo engineering in Norway during the summer of 1956. The course had 60 participants.

ties needed to be prioritised, not only by increasing the capacity at NTH, but also by arranging shorter courses for engineers and technicians. During the summer of 1956 the first in a long series of such courses was organised at NTH, see Figs. 2 and 3. The course was organised by the servo engineering group at NTH in collaboration with STU, NIF and NPI, the latter as the main source of funding. The goal of the course was to give engineers from the industry an introduction to control theoretic methods for automation of processes and working operations in industry. The number of applications turned out to be much larger than anticipated, and many applicants had to be rejected. During the two-week course 60 engineers received a solid introduction to the mysteries of control engineering.

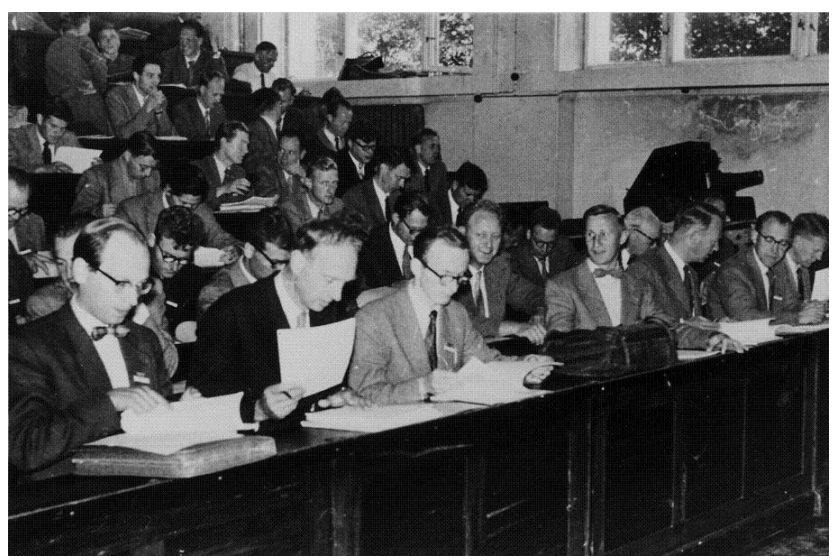

Figure 3: Participants at the summer course in 1956.

Even if the summer course was a success, there was a large need for more comprehensive education. At NTH the regular education had slowly started at the Electrotechnical department, see Fig. 4. This ac- 
tivity started through the employment of Jens Glad Balchen as an associate professor (dosent) in 1955 (NTH-archive (1954)). In the beginning control engineering was an elective course at the department, but the number of teaching hours and student numbers increased steadily. The department also grew considerably during the 1950s, see Balchen (1997) and Asphjell and Børresen (2004). In 1960, a full professorship in automatic control was created, and Balchen was promoted to this position in 1962 .

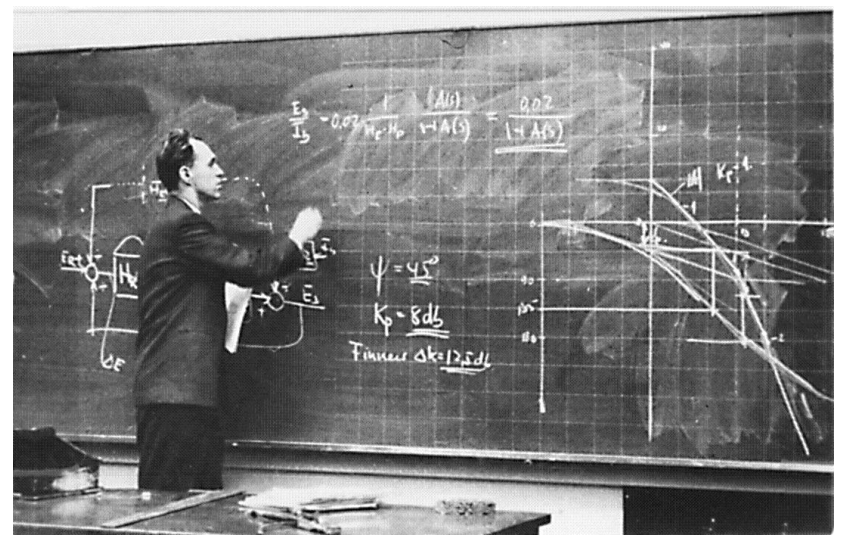

Figure 4: Associate professor (dosent) Jens Glad Balchen lecturing on block diagrams, transfer functions and Bode plots in the 1950 s.

\section{Politicians Enter the Scene}

At the same time as the first courses and education in automation was organised, the politicians and the trade unions started to get involved. To start with, the actors were DNA and LO. On the 10th to 11th February 1956 they jointly organised a conference with the title 'Technology and the Future' with almost 200 participants. There were presentations on both nuclear power and automation (LO and DNA (1956)). Both were disciplines which had appeared during and after the war, and many predicted that these two disciplines would play a major role in the industrial development in the coming years. In his opening speech, the LO leader Konrad Nordahl said the following: ... we can only compete with other nations with stronger infrastructures, if we understand and are able to make use of the new developments and experiences from scientists, current research and technology. ... About automation, it is said that it may lead to something like a new industrial revolution.

In a later speech, the Minster for Church and Education Birger Bergersen predicted that automation would play a deciding role in the development of Norwegian industry. The speakers from LO and DNA became proponents for the techniques of the future and drew connections with the modernisation of the Norwegian society. However, their embrace of the new technologies seems reluctant and their attitudes can be described as defensive. Repeatedly it was referred to the international development. Norway had to follow up on the new technology in order to not be left behind with respect to productivity and living standards. They were foremost worried about the national competitiveness. Similar thoughts are found in the book 'Automation. Ghost or Reality?' by the leader of LO's legal office and later Minister of Industry (Holler (1957)).

In connection with the elections in 1957 the topic of automation had found its way into the programs of the main political parties, showing an increasing interest for modern technology. By comparing the contents of the election flyers of the parties and the grants from the national parliament, there was a noticable disparity. Responses to the researchers' demands for increased efforts were mainly at the verbal level. For the politicians the primary focus was on the work and capital, while science and technology was secondary. For the servo enthusiasts the priorities were opposite.

\section{The First Projects}

In the budget for $1957 / 58$ NTNF funded five projects under STU. The main purpose of these initial projects was primarily to build up competence at the research institutions. However, two of the projects eventually led to prototypes which later became the foundation for industrial production, ISAC, see Fig. 5, and ESSI ${ }^{6}$.

One of the five projects had already been running for about a year. NPI had granted NOK 500,000 to a project called 'Efficiency improvement of Norwegian industry by automatic control'. This was a collaboration project between SI and CMI, where CMI focused on studies of single processes, while the SIresearchers aimed at developing a 'central controller'7.

\footnotetext{
${ }^{6}$ At SINTEF an instrument was developed which on the basis of recorded data could calculate statistical parameters. In 1961 an agreement was made with the company Noratom concerning transfer of the results. ISAC, which was the name of the instrument, later became one of Noratom's more profitable products. At SI the work led to the so-called ESSI system, a numerical control system for milling machines. In 1962 this system was put in production at Kongsberg Våpenfabrikk.

${ }^{7}$ Automatic control was realised by use of simple controllers whose task was to keep a physical quantity at a given level. In many cases, however, there was a need to use actuators at several places in a process, which led to a need for a relatively large number of controllers. In a large system there could be more than 100 single controllers. A central controller had the potential to replace all these controllers and hence make a continuous and improved quality control feasible. At the same time it would be possible to gain a better overview of
} 


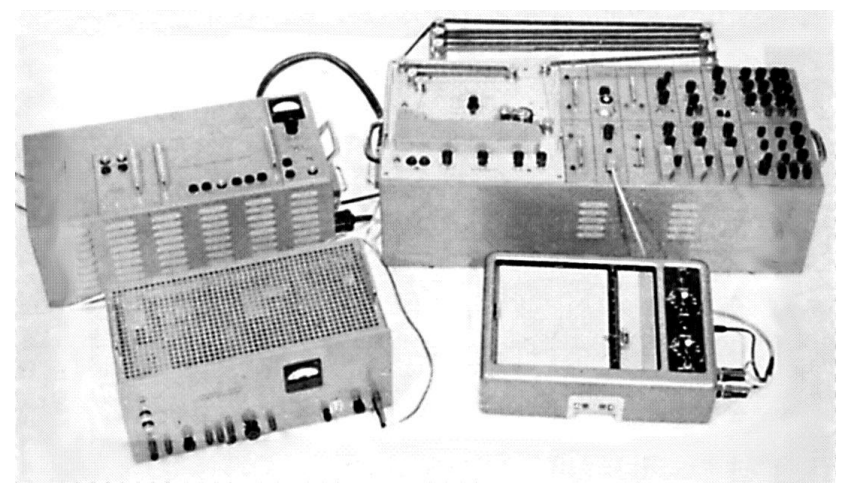

Figure 5: The ISAC instrument.

This project now received further funding from NTNF. In the application the following was predicted: If these two projects can be completed within reasonable time, they will place Norwegian industry in a much stronger position when it comes to automatic control and development of automated factories (NTNFarchive (1954a)).

In many ways, this large project can be seen as a concrete attempt to realise the dream of the automated factory. Despite the strong scepticism with regards to the feasibility of the project, STU still decided that SI could start evaluating the possibilities of a central controller. It soon became clear, however, that the sceptics were right. It became difficult to implement the project as described in the application. The researchers realised that the project was too ambitious and would be impossible to complete (Buset (1990)). Hence, the plans of a central controller were abandoned and efforts were concentrated on more restricted and better defined problems. In 1957 the ambitions were modified and the research was guided into a direction which later resulted in the ESSI unit. The central controller project came too early for many reasons. Digital control technology was not reliable enough, associated instruments were not available and the researchers did not understand the processes well enough. The dreams of the fully automated factory were more a 'pie in the sky' than a realistic project.

NPI and NTNF, which financed the project, can be seen as representatives for each of the two strategies introduced in Section 2. NPI represented work and capital while NTNF represented technology and science. The servo enthusiasts' position with respect to the two organisations was very convenient. The strategies of these two organisations made it possible for them to gain access to both, which had significance in several ways, not least when it came to funding of projects by balancing the emphasis of different aspects of au-

complicated processes, as stated in the application. tomation technology. In applications to NPI there was a much stronger emphasis on automation as a tool for increased productivity compared to the applications to NTNF. It was not the contents but rather the emphasis which distinguished the applications. The connections to NTNF were strong, but this was not the case with NPI which was used primarily as a source of funding (Holberg (1990)).

\section{The Network Grows}

The servo enthusiasts used a broad repertoir in the attempts to connect industry and research. In line with the STU recommendations of the need for a coordinated effort from industry and a strengthened contact between research institutes and companies, several automation companies were founded in the latter half of the 1950s. The first one was Bergens-Industriens Automatiserings-Selskap (BIAS) which was founded in $1957^{8}$. The purpose of BIAS was to promote the rationalisation of industry in the Bergen region, primarily by use of automation. The company had a close relation with the servo group at CMI and could in this way benefit from the researchers' competence (NPI-archive (1960)). BIAS engaged primarily in relatively simple forms of automation, or everyday-automation as it was called. Erik Olsson in BIAS described the activities in the following way: ... it is primarily what we call everyday-automation we have targeted ... it is not possible to push forwards with large and overwhelmingly costly installations. In the individual industrial companies there is a large number of detailed functions in the production processes. It is necessary to make sound choices with careful evaluation of practical-economical possibilities for automation (Dahl (1962)).

If one compares this statement with the perspectives presented by the servo enthusiasts, one is struck by the differences in dimensions. Since Norwegian industry consisted to a large extent of small and medium-sized companies of the same type as the member companies of BIAS, it is no wonder that the breakthrough for more advanced automation seemed long in coming. For the majority of Norwegian industry automation, restricted to limited parts of the production process was of much larger interest than advanced-level, fully automated production processes.

As an additional part of the networking of the servo

\footnotetext{
${ }^{8}$ The other automation companies were: Automatiseringsgruppen for Østlandet founded in 1957 by Produksjonsteknisk Forskningsinstitutt (PROFO), Jæren Automation Company in 1957, Stavanger-Industriens AutomatiseringsSelskap (SIAS) in 1958 and Sunnmøre Automatiseringsselskap in 1961. In Trondheim a course for automation in the industry was organised in February 1958, a collaboration between representatives in Trøndelag, NTH/SINTEF and NPI.
} 
enthusiasts, the Norwegian Society of Automatic Control (Norsk Forening for Automatisering, NFA) was founded in 1958, see Grønhaug (1958) and Dybing (1999). The idea behind the society was to achieve a better collaboration between researchers and the industry. The main purpose should be to encourage educational activities as well as collaboration between the various research institutes, the industry and other interested groups. From the beginning, NFA was associated with the International Federation of Automatic Control (IFAC) (Høivold (1985)). In addition to the connection to an international network, the society also kept close contact with international research groups, in particular in America. With connections to the internationally leading academics at MIT, the servo enthusiasts created a bridge between the research groups in Norway and leading international groups in the field.

The group in automatic control at NTH was towards the end of the 1950s one of the largest international research groups in the field. In 1955 the group was strengthened by the establishment of an additional SINTEF department for automatic control. By the end of the decade, the automatic control laboratory in Trondheim was singled out as one of OECD's Growing Points (Teknisk Ukeblad (1959)). This led to a large number of international visits, which gave the Norwegian researchers a solid base of international contacts.

Much of the activity in the establishment phase of the 1950s was initiated by a relatively small core of servo enthusiasts. These entrepreneurs had a common interest in promoting automation technology in Norway, an interest which tied them together. The close contact gave useful impulses and created a sort of servo family. At the same time the limited resources available created rivalry between the groups.

\section{New Focus - From Education and Competence Building to Industrial Applications}

Around 1960 it was claimed from several sources that Norway could no longer rely on traditional industry based on raw materials and inexpensive hydro power. The industry needed to change to more advanced production with a higher level of processing. This beginning breakthrough for the science and technology strategy also affected the attitudes towards research. There was a change of mentality in the industry with a growing interest for R\&D activities (Kvaal (1994)). The contacts between the research institutes and the industry, however, were not particularly strong. This led to an increased attention towards the relevance of research projects for industrial purposes. Hence, for
STU it became even more important to strengthen the contacts with the industry. The administration of the servo activities became more strongly aligned with industry-oriented goals. Hence, the STU strategies for the 1960 s became much more characterised by research based on the premises of the industry than what had been the case in the 1950s.

The focus on connecting research with the industry was always the main pillar in the work of the STU. The strategies for achieving this, however, were modified over time. Somewhat simplified, one can say that the main approach during the 1950s was the so-called linear model, where the industry were required to benefit from research based on the researchers premises. The purpose with the projects had so far been primarily to build up competence at the research institutes, and at the same time educate a large group of specialists for industry and research. Towards the end of the 1950s the importance of including the industry directly in the research projects was increasingly emphasised.

Many of the initial projects supported by the STU were within the area of process control and process investigations since the process industry had a significant importance for the national economy. As resources with respect to people and funding increased, STU aimed at supporting key problems in other areas with respect to a further automation of the industry and also the public administration.

During the 1950s the research funding available through STU gradually increased to about half a million NOK. Starting from the budget year 1959/60 available funding increased significantly. Several new schemes of servo activities were considered. There was a need for restructuring and new organisation. Through the scholarship scheme which came in 1959 it became possible for STU to fund research projects aimed at educating engineers who would later be employed in the industry. At the same time the contracts for $R \& D$ work were tightened. The purpose of the research funding had so far been twofold. As indicated by the name, these funds should be made available for R\&D work at the institutes. In addition, these funds should contribute to fulfilling another at least as important function. Given that the research institutes were in an establishment phase, the funding was granted in a form where the education and establishment activities were considered. This meant in practice that NTNF on purpose accepted low efficiency. After some time the institutes were developed to a level where it was no longer considered proper to fund education and establishment work through such contracts (Holberg (1959)). The new contracts focused on the importance of including an industrial partner in the research projects. 
It seems as if the members of STU gradually saw a need for a stronger administration of the development. There was a certain frustration in the committee and in the research institutes over the fact that they had not succeeded in transferring research results to the industry of the extent they had hoped for. This fact was likely an important motivation for the wish for a stronger administration. In the strategies of the committee there was now a particular focus on, together with the research institutes, to do the utmost to adapt actual research tasks closer to industrial requirements (NTNF-archive (1959)). There were also discussions on gathering the servo activities in Norway in one central servotechnical institute, to be able to focus better towards the industry. Due to a very strong opposition from the existing research groups, this proposal was put down. The plans for a Scandinavian institute were also torpedoed for the same reason.

Even if the situation in many ways seemed brighter for the servo enthusiasts after the changes, they seem to still have felt a need for additional steps in the approaches towards the industry. In a meeting of STU in 1962 the following points were made: It is the committee's perception that the understanding of automation as a strengthening factor for competitiveness in our industry has recently increased. It is therefore no longer necessary in the work of the committee to propagandise for automation as such. ... When we exclude the activities at NTH, we can no longer in our planning put a large emphasis on narrowly strengthening competence at the institutes. Our main problem today is to apply the knowledge which is already acquired. The current academic problems in automation require projects with access to relatively complex industrial systems (NTNFarchive (1962)).

This new orientation was expressed clearly when STU launched its strategy plan only a few months later. In the three-year plan from 1963 the committee presented a broad spectrum of projects. These represented a significant change towards the industry. STU presented a strategy towards the companies to a greater extent than before to focus on new opportunities which were not possible to calculate in exact detail. The committee also wanted to encourage the institutes to consider consequences of the practical limitations of the new technology, and also introduced development contracts directly with industrial companies. It was argued for a funding of a broader spectrum of projects with a stronger orientation towards the needs of the industry. In this way the committee hoped to guide the development in such a way that the research potentials were actively exploited for industrial expansion (NTNF-archive (1963)).

The autumn of 1964, nearly two years after the three- year plan was released, NTNF presented its comprehensive report on Norwegian scientific and industrial research. Several of the STU strategies made it into the NTNF report. In one of the appendices we find the recommendations from the committee for automation and data processing (NTNF (1964)). This committee's recommendations can in many ways be seen as a continuation of the main ideas in STU's three-year plan. One of the central topics in both was the question of how to connect research and industry in the best possible way. To this problem the new committee expressed the following views: In the coming five year period the efforts should be concretised about collaboration projects with Norwegian industry. This way, one has the best possibilities to solve problems related to the industry and to build up experience and academic competence within complex problems included in the areas of automation and data processing.

In the research report automation and data processing were treated together. It gradually became clear that automation and data processing problems to a large degree overlapped and were increasingly treated in the same context. In the autumn of 1966 NTNF decided to expand the responsibilities of STU to also include electronic data processing. In a meeting on November 22 the research council decided to replace the committee with the new committee for automation and data processing - the AUDA committee (NTNFarchive (1966)). The new committee started its work on January 1st, 1967. This was a reorganisation and strengthening of the STU rather than a closure. Continuity was ensured by the fact that half of the ten AUDA members came from STU. The biggest change was an increased area of responsibility, and not least that the industry became much stronger represented with six of ten members. ${ }^{9}$

\section{The Servo Enthusiasts as Avantgarde}

Until the reorganisation in 1966 STU had gradually strengthened its position, which resulted in servo activities being established as one of NTNF's special focus areas. What caused this strategic position and how did STU manage to get such a central role despite the lack of breakthroughs for the industry?

\footnotetext{
${ }^{9}$ The new members were: director Haakon Sandvold (ÅSV), chair, director Egil Abrahamsen (Det norske Veritas), director Jan Andersen (CMI), senior engineer Wilhelm Blakstad (De-No-Fa), senior engineer Tor Evjen (Norsk Hydro), senior engineer Anthon Fiksdahl (Myrens Verksted AS), director Leif Skare (Directorate for Rationalisation), professor Jens Glad Balchen (NTH), research director Karl Holberg (FFI) and engineer Thomas Hysing (SI).
} 
Gradually, strong servo engineering research groups were formed in Norway. NTH in Trondheim, CMI in Bergen and SI in Oslo all established strong automation groups. In addition groups were established at other institutions where servo research formed a part of the general activites. Of these groups, FFI was in a unique position both in terms of activities and size.

These servo groups gradually increased their impact during the 1960s. There had been considerable competence building, not only in the research institutions, but also in the industry through engineers graduating from NTH and various other courses. These factors, in addition to the increased efforts from STU to facilitate activities for industry, must have had significant impact on the breakthrough which could be sensed in the early 1960s. However, these internal factors alone do not fully explain the development. The external factors influencing the servo enthusiasts must also be taken into account. The increased interest in industry for scientific and technology-based research and the strengthening of the science and technology strategy (Kvaal (1994)), count to these external factors. This change of attitude was of fundamental importance, also for the servo enthusiasts' breakthrough towards industry. The focus of NTNF towards a stronger industry engagement from the first half the 1960s seems to have opened the possibilities and created room for the expansion plans of the servo enthusiasts.

Several sources support the use of an avantgarde label to characterise the work of STU, both from academic and functional perspectives. Support for the label can be found in the following reference from the acting director of NTNF, Robert Major: Through the work of STU, the committee manifested itself as a pioneering activity within the NTNF system, both from academic and functional perspectives. ... The committee's approaches became references for other committees and, in this way, they got impact for research and development work also in other activity areas (Torp and Major (1975)).

The strong position of STU within NTNF became more visible. When the project funding through the different committees of the research council are compared, STU stands out by the early concentration on a few but large projects. This dimensional thinking would later be extended to other parts of NTNF. The suggestion of placing development contracts directly with industrial companies did not get support initially, but later became one of the pillars in the research strategy (NTNF (1964)). The successful Taimyr project of STU, see Fig. 7, was the first in a series of socalled inter-institutional projects. This ship automation project was later used by NTNF as a scholarly example of a successful project (Abrahamsen (2003)).
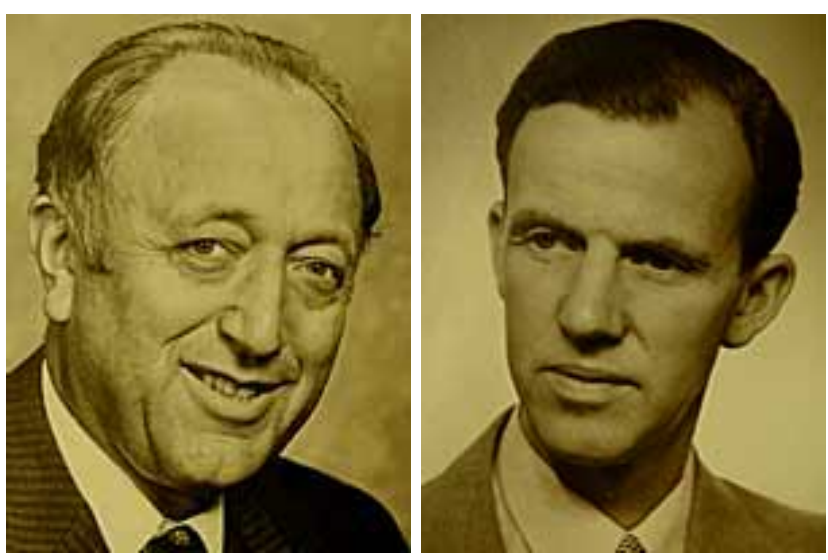

Figure 6: Haakon Sandvold (Left, 1972) and Robert Major (Right, 1956).

This way of organising a project, through a collaboration between several parties, later became the norm for a series of NTNF projects.

The funding for research through STU was always among the largest in an NTNF context. According to Major this level of funding was caused mainly by three factors: 1) The committee had a national plan, 2) The research field was considered important and 3) the committee consisted of very skilled people (Major (1990)). It was the combination of these three factors which gained STU it's strong position within the NTNF system.

As for the early phase, an additional factor of importance was the relatively low level of activity in the new field of research by the established research institutes. The research council recognised servo engineering as an important field, and saw it as an important task to build up new research groups. This fact influenced NTNF to be relatively generous with the funding, and they accepted that it would be used primarily for establishing groups rather than demanding efficiency.

As some of the projects which were funded through the STU entered a phase of commercial production, the position of STU was further strengthened. Examples of successful projects were the ESSI system and ISAC which became products with industrial applications. These examples gave STU legitimacy within the NTNF system during a time when questions were raised about the research council's ability to convert research ideas to industrial products. In the competition for funding it must have been a clear strength to be able to demonstrate commercial success stories. 


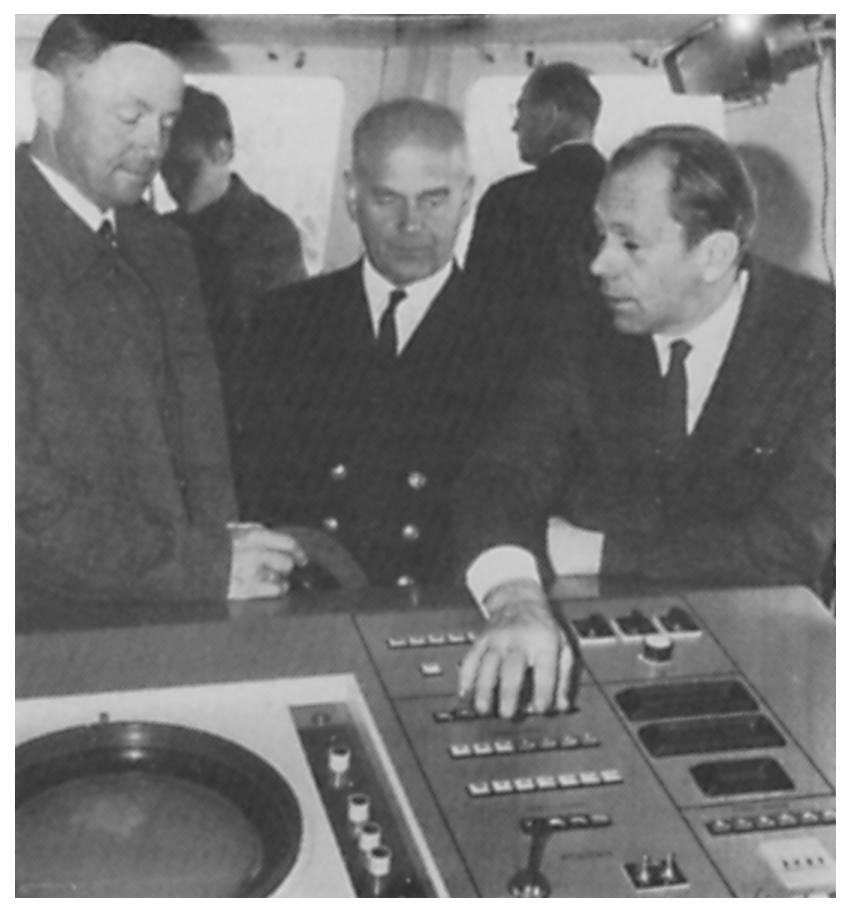

Figure 7: From the bridge of M/S Taimyr. Ibb Høivold from Norcontrol (right) in dicsussions with shipowner Wilhelmsen and captain Husum, see also Høivold (1984).

\section{The Servo Enthusiasts and the Industry}

STU put a large emphasis on finding methods of organising projects which resulted in strong connections between research and industry. During the years this emphasis resulted in a series of strategy documents where the main emphasis was gradually shifted from building competence in the institutes to building competence in the industry. The Taimyr project demonstrated that such an emphasis resulted in positive results.

The weak connections with the industry were all the time considered the central problem for STU, and the problem surfaced on many occasions. Even if contact was considered satisfactory in several projects, it was not considered satisfactory overall. The attitude from the industry was characterised by a view that automation was not a goal in itself, but they wished to make use of it within the framework of ordinary rationalisation whenever it could result in a profitable investment. Most of the industry's production was locked to a specific production equipment in a rigid framework for working routines and maintenance. A transfer to automatic operations would as a rule not only result in planning and purchase of new and expensive equipment, but also a radical change of the entire produc- tion and the organsiation around it. The companies were seldom interested in large-scale experiments with new methods. This lack of interest was also to a certain extent caused by the limited availability of venture capital.

The employees of the research institutions were mainly recruited from academic environments, with a competence anchored in theoretical knowledge. Insight into a series of new methods, familiarity with new equipment, and information about what had been achieved at other places by using these tools, gave the researchers the feeling of holding the key for great achievements in the industry. Most of what the researchers observed in the industry confirmed the impressions of obsolete technology, and it seemed as if numerous tasks waited for new solutions. In the threeyear plan from STU, it was written: The reseachers often get the feeling that the perspectives they see do not generate much enthusiasm, but rather continuous questions about how much the individual components will cost. Demands for safety reduce the possibilities for the real elegant solutions and practical considerations result in many trivial questions. Economical considerations make a complete transformation impossible to the extent that the researchers can not demonstrate the real possibilities (NTNF-archive (1963)).

Here we see a clear expression of a frustration where the industry's demands for profit-making often were seen as an obstacle for what the servo enthusiasts considered the best technical solutions. The frustration came about because of different preconditions at the institutes and the companies which made it difficult to collaborate. The progress had to be slower than the researchers wanted and with less certainty than the industry felt was needed.

It is interesting to note the mismatch between the breakthrough automation had within the NTNF system and the relatively weak response from the industry. There was plenty of research but only a few industrial success stories. The goal of initiating Norwegian production of servo components was continuously a central part of STU's strategy. Around 1960 the researchers finally succeeded in transforming their prototypes to commercial products. In the beginning, this happened by transferring the production rights to Norwegian or foreign companies. It was not easy to find Norwegian companies that wanted to or could start production of automation equipment. After initiatives from the researchers, some companies were established in the mid-1960s with the purpose of developing advanced automation, including: Norcontrol in Horten which worked with ship automation, Overby (1989), and Comtec in Trondheim which focused on process automation (Østby (1989)). Norcontrol's first product 
was a main-engine remote control system for dieseldriven ships.

\section{Missionaries for the Good Cause}

The work of STU can in many ways be characterised as missionary work for the good cause. When the servo enthusiasts initiated activities in the early 1950s, the optimism was palpable. The young engineers had grandiose visions about automation and its possibilities. These visions were expressed among others by the dream of the fully automated factory and the more technocratic visions about control engineering as an instrument and tool to realise a modern welfare society.

STU early put an emphasis on winning support in the industry for their automation ideas and in this way find applications for their knowledge. As the years passed it seems as if the 'message' was modified. In the early visions for how automation could revolutionise the production processes the practical problems were underestimated. The different strategies of STU involved an increasing focus on the need to directly involve the industry, see for example Campbell et al. (1956).

The dreams of the automated factory, the attempts of establishing a servo factory in the early 1950s, and the development of different industrial automatic machines, all demonstrate the servo enthusiasts propagating the science and technology strategy. At the same time they appeared through their 'mission' as exponents for the work and capital strategy of automation, connected with the application of automation to achieve increased efficiency. The same also held for the commissioned research.

Much had changed when STU was replaced by the AUDA committee. The ideology of automation had become much more concrete, and to a less degree connected to utopian visions. How had this development come about? Both external and internal factors seem to have had an impact. Towards the end of the 1960s it can be observed that the optimism about the future which was prominent among people in the 1950s was replaced by more pessimistic expectations. This change also affected the strategies of STU. Automation was increasingly presented as a necessity, or a guarantee for Norwegian industry not being outperformed in the international competition, rather than a promise of good times and better life quality. With the increasing unemployment during the 1960s, a greater fear followed that automation would become a threat towards many jobs and create even higher unemployment.

Contact with industrial reality seems to have led to a greater sobriety among the servo enthusiasts, and the visions were played down. The dreams of the auto- mated factory seem to have received the final blow in conjunction with the redefinition of the central regulator project. This dream was a phenomenon which belonged to the early 1950s. The chairman of STU, Haakon Sandvold, expressed it this way in Sandvold (1964): We smile today when we look back on the servo enthusiasts who after the war rolled up the sleeves and with an almost revolutionary eagerness wanted to automate industrial processes. It is true that these enthusiasts underestimated economical difficulties, sales problems, the value of practical insight which was already present in the industry by engineers in other disciplines, workers and supervisors. The instrumentation for important variables were at the time not developed, and even worse, the understanding of what needed to be measured was lacking. Despite all these factors their main principles have been proven right.

Even if the visions were not possible to realise fully in their original form, it still seems that they influenced the development. In newspaper and journal articles from this period it can be observed that the thoughts had appeal also outside the ranks of the servo enthusiasts. It is likely that the connection of the technological visions with the visions for the development of society contributed to the significant attention that automation received.

Further, it is not unreasonable to assume that perspectives for the future also influenced the relatively generous funding that the servo enthusiasts received. Maybe these optimistic visions were a necessary precondition for their successes in funding projects. They managed to build up large research groups despite the fact that the practical importance of the projects was limited. The research groups were in no way characterised by lack of ideas, and the Norwegian research in servo engineering was at the international forefront. The main problem was to transfer the research results to industrial production.

The servo enthusiasts continuously argumented for automation in light of a broader development of society. National considerations were strongly accentuated and played an important role in their visions. In the strategic plans that STU presented, the argumentation for automation was to a large degree woven around economical perspectives for the nation and for the industry. Automation was presented as a tool for ensuring innovation and to promote economic growth. The servo enthusiasts appeared as suppliers of competence and methods to create a modern Norway.

It seems as if the many aspects of the servo enthusiasts' visions appealed outside the group of people interested in technology and the economy. Despite a certain scepticism for unwanted concerns for workers, it seemed as if the visions about the 'good life' appealed 
to many. The servo enthusiasts attached concrete examples to the general optimism about the future, which was at least until the mid-1960s still quite strong in the population. One can say that the enthusiasts through their visions and work presented a glimpse into the 'promised land'.

Even if the direct industrial implications of the servo groups' activities were limited, their work had an impact for the long-term. By the establishment of an educational program at NTH led by Jens Glad Balchen, in addition to an active information and propaganda activity, the understanding of the benefits of automation increased in the industry. In this way, the implementation of automation gradually gained momentum. In retrospect one may claim that for the long-term, this was the most significant effect of STU and the efforts of the servo enthusiasts to transfer automation technology from the laboratories into industrial application.

\section{References}

Abrahamsen, E. Fakultet for marin teknikk - en veiviser for den marine klynge. In: S. Kvaal, T. Moan, J. Moe and G. Wilhelmsen (red.): Et hav av muligheter. Skipslinjen ved NTH og Fakultet for marin teknikk ved NTNU 1910-2001. Trondheim: Tapir akademisk forlag and Institutt for marin teknikk, pp. 335-336. 2003.

Andersen, H. Et kort riss av informasjonsteknologiens utvikling. In P.M. Schiefloe and K.H. Sørensen (eds.): Revolusjonen som forsvant? EDB, informasjonsteknologi og samfunn, pp. 49-94. 1986.

Asphjell, A. and Børresen, A. Institutt for teknisk kybernetikk 50 år. 2004. NTNU.

Balchen, J. G. Teknisk kybernetikk - et fagområde i sterk vekst. In: M. Hård, A. Kjærvik, S. Kvaal, P.K. Larsen, O. Lauritzen and E. Rødahl: Teknologi for Samfunnet. NTH i en brytningstid 1985-1995. Trondheim: NTNU, pp. 140-141. 1997.

Balchen, J. G. Note in private archive. Unknown date.

Barlaup, A. The Royal Norwegian Council for Scientific and Industrial Research (NTNF). Ten year report 1946-1956. 1956.

Blakstad, W. Views in conjunction with industrial instrumentation. Teknisk Ukeblad, no. 22, pp. 469, 1960 .

Buset, H. Presentation at servo seminar at Holmenkollen Park Hotel, 28-30 sept. 1990.
Callon, M. Society in the Making: The Study of Technology as a Tool for Sociological Analysis. 1987.

Campbell, D., Sandvold, H., and Buset, H. Automation of Norwegian industry. Report from NPI-project No. 29, Bergen, Oslo. 1956.

Dahl, P. Hverdagsautomatikk i Bergens-industri. Mirakler hos BIAS. Interview with engineer Erik Olsson (BIAS), Bergens Arbeiderblad 27. Oct. 1962.

Dybing, B. NFA 40 år 1958-1998. 1999. Oslo: Norsk Forening for Automatisering.

Feedback Control Committee. NTNF-archive, Minutes from the Meetings in 'Servoteknisk Utvalg', 5. Nov. and 6. Dec. 1950.

Grønhaug, O. Minutes from the founding meeting in the Norwegian Society of Automatic Control, 10. Oct. 1958.

Høivold, I. Norwegian Research and Development in the Field of Ship Automation. Modeling, Identification and Control, 1984. 5(3):171-178. doi:10.4173/mic.1984.3.4.

Høivold, I. Mine engasjementer i norsk elektronikkvirksomhet. Notes from seminar at Sørnesset, 5. Oct. 1985.

Holberg, K. NTNF-archive, Minutes from the first Servo Meeting at Kjeller, 26. Jan. 1954.

Holberg, K. NTNF-archive, Feedback Control Committee. Note concerning use of contracts for research and development work. 1959.

Holberg, K. Interview dated 23. Nov. 1990.

Holler, K. Automation. Ghost or Reality? Aschehoug, Oslo, 1957.

Jenssen, M. NTNF-archive, Feedback Control Committee: Orientation to the Feedback Control Committee Meeting. 10. Sept. 1950.

Kvaal, S. Drømmen om det moderne Norge. Automasjon som visjon og virkelighet i etterkrigstiden. STS-rapport nr. 13, Senter for teknologi og samfunn, Universitetet $i$ Trondheim, 1991.

Kvaal, S. Forskning og industripolitikk. Om gjennombruddet for forskning i industripolitikken. Historisk tidsskrift, 1994. (1):72-93.

Kvaal, S. Janus med tre ansikter. Om organiseringen av den industrielt rettede forskningen i spennet mellom stat, vitenskap og industri $i$ Norge, 1916-1956. Ph.D. thesis, NTNU, 1997. Nr. 21 i Skriftserie fra 
Historisk Institutt. Akademisk avhandling. Historisk institutt, HF-fakultetet, Senter for teknologi og samfunn.

Latour, B. Science in Action. How to follow Scientists and Engineers through Society. Milton Keynes: Open University Press, 1987.

LO and DNA. Arbeidernes faglige Landsorganisasjon og Det norske Arbeiderparti: Teknikken og Framtiden. DNAs hustrykkeri, Oslo, 1956.

Major, R. Interview dated 19. Nov. 1990.

Njølstad, O. Strålende forskning. Institutt for energiteknikk 1948-98. Tano Aschehoug, Oslo, 1999.

Njølstad, O. and Wicken, O. Kunnskap som våpen. Forsvarets forskningsinstitutt 1946-1975. Tano Aschehoug, Oslo, 1997.

Noble, D. Forces of Production. A Social History of Industrial Automation. Oxford University Press, New York, 1986.

NPI-archive. Project folder NPI-126. BergensIndustriens Automatiserings-Selskap: Kort orientering om BIAS' virksomhet. 19. Jan. 1960.

NTH-archive. Utskrift fra professorrådets forhandlingsprotokoll, sak 185/54, møte 1. juni. 1954.

NTNF. NTNF's comprehensive research analysis. Appendix 17, Automation and Data Processing, Oslo. 1964.

NTNF-archive. Feedback Control Committee. Proposal from CMI and SI to NPI about measures for efficiency improvements of Norwegian industry by automatic control, 16. Sept. 1954a.

NTNF-archive. Minutes from the advisory meeting No. 4/54, Case 54, 13. Dec. 1954b.

NTNF-archive. Minutes from meeting in the Feedback Control Committee, 12. Jan. 1959.

NTNF-archive. Minutes from meeting in the Feedback Control Committee, 28-29. Nov. 1962.

NTNF-archive. Feedback Control Committee. NTNF. 3-year-plan for the period 1964 - 1966. Jan. 1963.

NTNF-archive. Minutes from the council meeting No. 4/66, item 8, Nov. 22. 1966.

Østby, P. The Comtec Case. STS-report No. 8, Centre for Technology and Society, UNIT. 1989.
Overby, S. From research to industry. Establishment of the ship automation company Norcontrol. Teknologihistorie-prosjektet, NAVF-NTNF. Report nr. 2. 1989.

Sandvold, H. NTNF-archive, Feedback Control Committee, Note 5. Oct. 1951.

Sandvold, H. NTNF-archive, Memorandum, 13. Aug. 1953.

Sandvold, H. NTNF-archive, Memo about establishment of Feedback Control Committee, 23. Oct. 1954.

Sandvold, H. Automation and Norwegian Industry. A Status Report and Evaluation of Future Possibilities. Teknisk Ukeblad, No. 14, pp. 331, April 4. 1964.

Teknisk Ukeblad. 'Growing Points' - Nordiske vekstsentra og stipendier for utdannelse av høyt kvalifisert teknisk-naturvitenskapelig personell. 1959. No. 16, 16. Apr.

Torp, K. and Major, R. In private archive of J.G. Balchen. Letter dated 31. Dec. 1975.

Vi Vet. Fra forskningens og vitenskapens verden. Tiden Norsk Forlag, Oslo, 1952.

Wiener, N. Cybernetics. Or Control and Communication in the Animal and the Machine. J. Wiley, New York, 1948. 